\title{
Effects of pyridoxal-5' - phosphate (MC-1) in patients undergoing high-risk coronary artery bypass surgery: Results of the MEND-CABG randomized study
}

Jean-Claude Tardif, MD, ${ }^{a}$ Michel Carrier, MD, ${ }^{a}$ David E. Kandzari, MD, ${ }^{\mathrm{c}}$ Robert Emery, MD, ${ }^{\mathrm{d}}$ Robert Cote, MD, Therese Heinonen, DVM, ${ }^{\mathrm{b}}$ Marjorie Zettler, $\mathrm{PhD},{ }^{f}$ Vic Hasselblad, $\mathrm{PhD},{ }^{c}$ Marie-Claude Guertin, $\mathrm{PhD},{ }^{\mathrm{b}, \mathrm{e}}$ and Robert $A$. Harrington, $M D{ }^{c}$ on behalf of the MEND-CABG Investigators

See related editorial on page 1409.

Supplemental material is available online
From the Montreal Heart Institute ${ }^{\mathrm{a}}$ and Université de Montréal, the Montreal Heart Institute Coordinating Center, ${ }^{\text {b }}$ Montreal, Canada; Duke Clinical Research Institute, ${ }^{\mathrm{c}}$ Durham, NC; Minnesota Heart and Vascular Center, ${ }^{\mathrm{d}}$ Edina, Minn; the Montreal General Hospital, ${ }^{\mathrm{e}}$ Montreal, Canada; and Medicure, ${ }^{\mathrm{f}}$ Winnipeg, Canada.

Michel Carrier, David Kandzari, and Robert Harrington report grant support from Medicure; Robert Emery reports consulting fees from Medicure; Marjorie Zettler is an employee of Medicure. The study was sponsored by Medicure.

Received for publication July 7, 2006; revisions received Dec 21, 2006; accepted for publication Jan 2, 2007.

Address for reprints: Jean-Claude Tardif, MD, Montreal Heart Institute, $5000 \mathrm{Be}-$ langer Street, Montreal, H1T 1C8, Canada (E-mail: jean-claude.tardif@icm-mhi.org).

J Thorac Cardiovasc Surg 2007;133:1604-11 $0022-5223 / \$ 32.00$

Copyright (๑) 2007 by The American Association for Thoracic Surgery

doi:10.1016/j.jtcvs.2007.01.049
Objective: Coronary artery bypass graft surgery remains associated with significant postoperative cardiovascular morbidity and mortality in high-risk patients. MC-1 (pyridoxal-5' -phosphate monohydrate) inhibits purinergic receptors and intracellular influx of $\mathrm{Ca}^{2+}$, thereby reducing cellular injury during experimental ischemia and reperfusion. The MEND-CABG trial tested the hypothesis that MC-1 reduces cardiovascular morbidity and mortality after coronary artery bypass graft.

Methods: In a phase 2, double-blinded, placebo-controlled study, 901 patients scheduled for coronary artery bypass graft surgery with cardiopulmonary bypass and at high risk for subsequent cardiac or neurologic complications were randomly assigned to receive oral MC-1 (250 mg or $750 \mathrm{mg} / \mathrm{d}$ once daily) or placebo beginning 3 to 10 hours prior to surgery and continued to postoperative day 30 .

Results: At 30 days, MC-1 $250 \mathrm{mg}$ (compared with placebo) reduced the composite of death, nonfatal cerebral infarction, and nonfatal myocardial infarction by $14.0 \%(P=.3124)$ with peak creatinine kinase-myocardial band $\geq 50 \mathrm{ng} / \mathrm{mL}$ (prespecified primary end point); 32.3\% $(P=.0349)$ with peak creatinine kinase-myocardial band $\geq 70 \mathrm{ng} / \mathrm{mL}$; and $37.2 \%(P=.0283)$ with peak creatinine kinase-myocardial band $\geq 100 \mathrm{ng} / \mathrm{mL}$. Myocardial infarctions with peak creatinine kinase-myocardial band $\geq 100 \mathrm{ng} / \mathrm{mL}$ were reduced by $47.2 \%$ in the MC-1 250-mg group versus placebo $(P=.0083)$. Greater efficacy was demonstrated with $250 \mathrm{mg}$ than with the $750-\mathrm{mg}$ dose of MC-1.

Conclusions: In high-risk patients undergoing coronary artery bypass graft, treatment with MC-1 did not significantly affect the prespecified primary end point but was associated with a significant reduction in perioperative myocardial infarction with creatinine kinase-myocardial band $\geq 100 \mathrm{ng} / \mathrm{mL}$. A larger, well-powered trial is needed to evaluate the cardioprotective effects of MC-1.

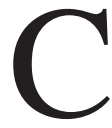
oronary artery bypass graft (CABG) surgery effectively relieves angina and results in longer survival in specific subgroups of patients with complex coronary disease and left ventricular dysfunction..$^{1-3}$ Due to the high incidence of coronary artery disease worldwide, as well as the effectiveness of this surgical procedure, CABG surgery makes up 1 of the top 10 most frequently performed procedures in North America and Europe. ${ }^{4,5}$ Despite the benefits of CABG surgery, the procedure is associated with a risk of perioperative mortality, myocardial infarction, unstable angina, heart failure, life-threatening arrhythmia, renal insufficiency, and stroke, often due to episodes of ischemia and reperfusion. ${ }^{6-10}$ The impact of these complications is significant with incidence rates of death and major cardiovascular and cerebrovascular events following CABG surgery of up to $20 \%$ depending on the patient's risk profile and diagnostic criteria. ${ }^{11-16}$ 


$$
\begin{aligned}
& \text { Abbreviations and Acronyms } \\
& \begin{aligned}
\text { ATP } & =\text { adenosine triphosphate } \\
\text { CABG } & =\text { coronary artery bypass graft } \\
\text { CEC } & =\text { Clinical Endpoint Committee } \\
\text { CK-MB } & =\text { creatinine kinase-myocardial band } \\
\text { ECG } & =\text { electrocardiogram } \\
\text { MI } & =\text { myocardial infarction } \\
\text { P-5'-P } & =\text { pyridoxal-5'-phosphate monohydrate } \\
\text { PCI } & =\text { percutaneous coronary intervention } \\
\text { POD } & =\text { postoperative day }
\end{aligned}
\end{aligned}
$$

Although advances in surgical techniques, anesthetic management, and postoperative care have resulted in a steady decline in post-CABG morbidity and mortality during the past 2 decades, ${ }^{17,18}$ there clearly remains a need to reduce the number of complications associated with cardiac surgery. Considering the substantial number of patients who undergo CABG every year along with the incidence of sequelae, cardioprotection and neuroprotection represent significant unmet medical needs.

MC-1 is an investigational drug that contains pyridoxal$5^{\prime}$-phosphate monohydrate (P-5'-P). P-5'-P is a naturally occurring metabolite of pyridoxine and is formed in mammalian cells by phosphorylation and oxidation reactions. MC-1 is a purinergic ( $\mathrm{P} 2)$ receptor antagonist that blocks intracellular influx of $\mathrm{Ca}^{2+}$, thereby reducing cell damage during experimental episodes of ischemia and reperfusion. ${ }^{19}$ A phase 2 dose-ranging, single-blinded study (MEND-1) evaluated the effects of $10 \mathrm{mg} / \mathrm{kg} / \mathrm{d}$ MC- 1 given for up to 14 days in patients at high risk for ischemic complications during percutaneous coronary intervention (PCI) ${ }^{20}$ Results demonstrated a decrease in infarct size over the first 24 hours following PCI, suggesting the cardioprotective properties of MC-1 in the setting of ischemia and reperfusion. The MC- 1 to Eliminate Necrosis and Damage in CABG (MEND-CABG) trial was a phase 2 study that intended to evaluate the potential cardio- and neuroprotective effects of MC-1 in patients undergoing CABG with cardiopulmonary bypass and considered at high risk for perioperative vascular events.

\section{Materials and Methods}

\section{Study Design and Patient Selection}

Following approval by individual Ethics Committees and Institutional Review Boards, enrollment for the double-blinded, placebocontrolled MEND-CABG trial was conducted at 40 centers in Canada and the United States (Appendix E1) between April 2004 and July 2005. Patients eligible for the study were those scheduled for CABG surgery with cardiopulmonary bypass but without associated valve surgery who were considered at high risk for perioperative cardio- and/or cerebrovascular complications according to 2 or more of the following criteria: age $>65$ years; current smoker; history of diabetes mellitus requiring treatment other than diet; history of nondisabling stroke, transient ischemic attack, or carotid endarterectomy; prior peripheral artery surgery or angioplasty; recent myocardial infarction (MI) ( $\geq 48$ hours and $\leq 6$ weeks before surgery); evidence of left ventricular dysfunction or congestive heart failure; need for urgent $\mathrm{CABG}$; renal dysfunction with serum creatinine between 133 and $<250 \mu \mathrm{mol} / \mathrm{L}(1.5-2.8$ $\mathrm{mg} / \mathrm{dL})$; or presence of stenosis $(\geq 50 \%)$ in $\geq 1$ carotid artery. Patients with planned associated valve surgery, concurrent carotid endarterectomy, aortic dissection repair, aortic root reconstruction, or surgery for atrial fibrillation were excluded, as were patients with current cardiogenic shock, left ventricular rupture, ventricular septal rupture, papillary muscle rupture, uncontrolled diabetes [fasting plasma glucose $\geq 24 \mathrm{mmol} / \mathrm{L}$ (432 mg/dL)], creatinine $\geq 250 \mu \mathrm{mol} / \mathrm{L}(2.8 \mathrm{mg} / \mathrm{dL})$, liver cirrhosis, chronic active hepatitis, severe liver dysfunction, MI occurring $<48$ hours prior to planned CABG surgery, history of malignancy during the last 5 years, potential for pregnancy, or history of alcohol or drug abuse within the past year. Finally, patients who could not be screened at least 4 hours before the scheduled CABG were excluded.

After written informed consent was obtained, patients were randomly assigned in a 1:1:1 ratio (using an interactive voice response system) to receive MC-1 $250 \mathrm{mg}$, MC-1 $750 \mathrm{mg}$, or matching placebo tablets administered orally once daily. The first dose of study medication was administered 3 to 10 hours prior to CABG surgery and treatment continued for 30 days after surgery. During CABG surgery, the use of cardiopulmonary bypass, moderate systemic hypothermia $\left(34^{\circ} \mathrm{C}\right)$, and routine anticoagulation were required per protocol. Patients unable to swallow pills postoperatively were allowed to receive study medication through a nasogastric tube. During the 90 -day postoperative period, patient observations were carried out through 72 hours, at postoperative day (POD) 4, at discharge, at POD 30, and at POD 90.

\section{Study End Points and Definitions}

The primary efficacy end point was the difference between treatment groups in the combined incidence of cardiovascular death, nonfatal MI, and nonfatal cerebral infarction up to and including POD 30. Secondary efficacy end points included individual components of the combined end point, area under the curve of creatinine kinase-myocardial band (CK-MB) within the first 24 hours post-CABG, all-cause mortality, and composite and component end points up to POD 90. An independent Clinical Endpoint Committee (CEC) composed of cardiologists and neurologists experienced in patient care reviewed all potential episodes of the primary end point components, and their determination was used in the final analysis. Each reported death, stroke, and MI was classified according to predetermined guidelines. All deaths without an identifiable noncardiovascular cause were attributed to a cardiovascular cause. Myocardial infarction was defined based on central laboratory or core electrocardiogram (ECG) laboratory data as follows: (1) a peak CK-MB value $\geq 50 \mathrm{ng} / \mathrm{mL}$, or $\geq 35 \mathrm{ng} / \mathrm{mL}$ with ECG evidence of Q-wave, on days up to and including POD $4 ; 2$ ) a peak $\mathrm{CK}-\mathrm{MB} \geq 25 \mathrm{ng} / \mathrm{mL}$ or new Q-wave occurring after POD 4; or (3) a Q-wave or non-Q-wave MI identified by the investigator and confirmed by the CEC. In addition, other previously used criteria ${ }^{13}$ were also applied to the definition of nonfatal MI (and composite end point) as a post hoc analysis. For patients 
with CK-MB contributing as at least 1 source of the suspected event, the additional definitions of $\mathrm{CK}-\mathrm{MB} \geq 70 \mathrm{ng} / \mathrm{dL}$ and $\mathrm{CK}-\mathrm{MB} \geq 100 \mathrm{ng} / \mathrm{dL}$ were applied to the adjudicated population to identify patients with more significant myocardial damage.

Patient blood samples were collected before CABG surgery (baseline) and 4, 8, 12, 16, 24, 36, 48, 72, and 96 hours and 30 and 90 days after $\mathrm{CABG}$ surgery. All samples were submitted to a central laboratory (Cirion BioPharm Research, Inc, Laval, Quebec, Canada) for CK-MB measurements. Electrocardiograms were performed at baseline, on POD 2, 4, 30, and 90 and analyzed according to the Minnesota Code ${ }^{21}$ by an independent core laboratory (Dynacare Laboratories, Edmonton, Alberta, Canada). All unscheduled CK-MB determinations and ECGs were also recorded and adjudicated by the CEC.

Cerebral infarction was defined as any new sudden onset focal neurologic deficit lasting $\geq 24$ hours following exclusion of intracranial hemorrhage by imaging (computed tomography scan or magnetic resonance imaging). All patients suspected clinically of having a stroke or transient ischemic attack were required to undergo a neurologic examination (conducted by a neurologist or internist with expertise in cerebral vascular disease) within 24 hours of onset of symptoms, in addition to cerebral imaging.

\section{Statistical Methods}

The sample size estimate assumed a primary event rate of $15 \%$ with placebo. In this phase 2 study, a sample size of 300 patients per treatment group had $78 \%$ power to detect a relative reduction of $37 \%$ in any of the 2 active groups with a 2-sided significance level of .20 for both comparisons with placebo. The primary analysis compared the incidence in each active treatment group with that in the placebo group using $2 \chi^{2}$ tests: 1 for the comparison of MC-1 $250 \mathrm{mg} / \mathrm{d}$ versus placebo and 1 for the comparison of MC-1 $750 \mathrm{mg} / \mathrm{d}$ versus placebo with no adjustments for multiple comparisons. End points were computed on a per-patient basis. For the components of the primary efficacy end point at POD 30 and for the composite end point at POD 90, $\chi^{2}$ tests comparing the 3 groups were used. If significant, $\chi^{2}$ tests with 1 degree of freedom were performed for comparisons against placebo. For the components of the primary efficacy end point at POD 90, analyses were based on time to event and groups were compared using log-rank tests. Again, pairwise comparisons were undertaken only when the overall comparison was significant. Areas under the curve of CK-MB were compared across groups using an analysis of variance. Aside from the primary analysis, all other statistical tests were performed at a significance level of .10.

\section{Trial Organization}

A Steering Committee supervised the scientific conduct of the study, and an independent Data and Safety Monitoring Board oversaw safety and ethical issues. The clinical sites, CEC, ECG Core Laboratory, and Central Laboratory shared the responsibility of identifying potential end point events, and the CEC was responsible for adjudicating all of them. Project management, data management, and Canadian site management were conducted by the Montreal Heart Institute Coordinating Center (Montreal, Canada), which also prepared the randomization codes. Site management in the United States was conducted by Duke Clinical Research Institute (Raleigh, NC). Statistical analyses were performed by the
Montreal Heart Institute Coordinating Center independently of the sponsor. Medicure Inc (Winnipeg, Canada) sponsored the study.

\section{Results \\ Patient Characteristics}

The demographics and clinical characteristics of the 901 randomized patients were relatively well balanced between the 3 treatment groups (Table 1). There were slightly fewer patients with prior MIs, hypertension, heart failure, recent $\mathrm{MI}$, and need for urgent $\mathrm{CABG}$ in the placebo group and slightly more patients with prior PCIs, diabetes, and peripheral vascular disease. Overall, the mean patient age was 66 years (range, 34-95 years), and 79\% of patients were men. The patients' flow in the study is shown in Figure 1.

\section{Efficacy Analyses}

Of the 901 patients, $217(24.1 \%)$ reached the prespecified primary end point at POD 30 defined as cardiovascular death, nonfatal cerebral infarction, and nonfatal MI (peak CK-MB $\geq 50 \mathrm{mg} / \mathrm{mL}$ ) distributed as follows: $25.1 \%(75 /$ 299) placebo, $21.6 \%$ (65/301) $250 \mathrm{mg} / \mathrm{d} \mathrm{MC}-1$, and $25.6 \%$ (77/301) $750 \mathrm{mg} / \mathrm{d} \mathrm{MC}-1$ (Table 2). At 30 days, the 250-mg dose of MC-1 reduced the combined end point of cardiovascular death, nonfatal cerebral infarction, and nonfatal MI by $14.0 \%(P=.3124)$ with peak $C K-M B \geq 50 \mathrm{ng} / \mathrm{mL}$; $32.3 \%(P=.0349)$ with peak CK-MB $\geq 70 \mathrm{ng} / \mathrm{mL}$; and $37.2 \%(P=.0283)$ with peak CK-MB $\geq 100 \mathrm{ng} / \mathrm{mL}$. Compared with placebo, MC-1 $250 \mathrm{mg}$ reduced MIs with peak $\mathrm{CK}-\mathrm{MB} \geq 50 \mathrm{ng} / \mathrm{mL}$ by $15.2 \%(P=.2988)$, MIs with peak $\mathrm{CK}-\mathrm{MB} \geq 70 \mathrm{ng} / \mathrm{mL}$ by $37.6 \%(P=.0192)$, and MIs with peak $\mathrm{CK}-\mathrm{MB} \geq 100 \mathrm{ng} / \mathrm{mL}$ by $47.2 \%(P=.0083)$.

MC-1 $750 \mathrm{mg}$ did not significantly affect the composite primary end point when more restrictive $\mathrm{CK}-\mathrm{MB}$ criteria were employed. However, MC-1 $750 \mathrm{mg}$ reduced MIs with peak CK-MB $\geq 100 \mathrm{ng} / \mathrm{mL}$ by $47.2 \%$ ( $P=.0083$ ) compared with placebo at POD 30. Among patients with adjudicated MIs, the area under the curve of CK-MB (0-24 hours) was $1765.5 \pm 1148.7$ in the placebo group, $1581.5 \pm$ 1071.9 in the MC-1 250-mg group, and $1397.9 \pm 962.7$ in the MC-1 750-mg arm $(P=.1737)$. Finally, similar trends as those described at POD 30 were observed at POD 90 (Table 3).

\section{Safety Analyses}

MC-1 administered for 30 days was generally well tolerated. Both in the MC-1 and placebo groups, $69 \%$ to $73 \%$ of the patients experienced $\geq 1$ adverse event from randomization to POD 4 or from POD 4 to end of trial (Table 4). Most events were considered to be mild to moderate in intensity. Notably, the incidence of hypotension up to POD 4 was slightly higher with MC-1 $750 \mathrm{mg}$, as was vomiting from POD 4 to the end of the trial. Finally, the incidence of atrial fibrillation from POD 4 to end of trial was $11.9 \%$ with 
TABLE 1. Characteristics of the study population

\begin{tabular}{|c|c|c|c|c|}
\hline & $\begin{array}{l}\text { Placebo } \\
\text { (n = 299) }\end{array}$ & $\begin{array}{c}\text { MC-1 } 250 \mathrm{mg} \\
(\mathrm{n}=301)\end{array}$ & $\begin{array}{c}\text { MC-1 } 750 \mathrm{mg} \\
(\mathrm{n}=301)\end{array}$ & $\begin{array}{c}\text { All } \\
(n=901)\end{array}$ \\
\hline Sex (\% male) & 80.3 & 76.7 & 79.1 & 78.7 \\
\hline Age (mean y $\pm S D$ ) & $66 \pm 10$ & $65 \pm 11$ & $65 \pm 10$ & $66 \pm 10$ \\
\hline Race (\% Caucasian) & 93.3 & 92.0 & 93.4 & 92.9 \\
\hline Previous MI (\%) & 51.4 & 58.8 & 56.3 & 55.5 \\
\hline Previous PCI (\%) & 25.8 & 20.7 & 20.6 & 22.4 \\
\hline Previous CABG (\%) & 3.7 & 2.7 & 3.7 & 3.3 \\
\hline Angina (\%) & 82.1 & 79.7 & 78.1 & 80.0 \\
\hline Atrial fibrillation (\%) & 5.1 & 6.0 & 4.7 & 5.2 \\
\hline Silent ischemia (\%) & 6.8 & 5.2 & 8.4 & 6.8 \\
\hline Hypertension (\%) & 72.5 & 77.0 & 74.4 & 74.6 \\
\hline Diabetes (\%) & 46.2 & 39.6 & 43.8 & 43.1 \\
\hline Hypercholesterolemia (\%) & 82.8 & 79.7 & 80.1 & 80.9 \\
\hline Peripheral vascular disease (\%) & 17.6 & 14.4 & 17.6 & 16.5 \\
\hline Congestive heart failure (\%) & 13.5 & 19.8 & 15.1 & 16.1 \\
\hline Current smoker $(\%)$ & 29.8 & 27.6 & 26.8 & 28.0 \\
\hline History of diabetes mellitus requiring treatment other than diet $(\%)$ & 43.8 & 36.5 & 41.1 & 40.5 \\
\hline Evidence of LVD or CHF (\%) & 21.1 & 30.2 & 27.8 & 26.4 \\
\hline History of nondisabling stroke, TIA, or endarterectomy (\%) & 12.0 & 12.0 & 12.9 & 12.3 \\
\hline Urgent $C A B G$ intervention required $(\%)$ & 71.9 & 76.4 & 77.8 & 75.4 \\
\hline History of Ml 48 hours to 6 weeks prior to study entry (\%) & 24.1 & 28.6 & 27.5 & 26.7 \\
\hline Prior peripheral artery surgery or angioplasty $(\%)$ & 17.4 & 12.0 & 11.3 & 13.5 \\
\hline Creatinine $133-250 \mu \mathrm{mol} / \mathrm{L}(\%)$ & 8.0 & 8.3 & 7.9 & 8.1 \\
\hline Presence of at least 1 carotid artery stenosis $>50 \%(\%)$ & 7.7 & 5.6 & 5.0 & 6.1 \\
\hline Age $>65$ years ( $\%$ patients $)$ & 58.5 & 54.2 & 54.6 & 55.8 \\
\hline
\end{tabular}

$M I$, Myocardial infarction; $P C l$, percutaneous coronary intervention; $C A B G$, coronary artery bypass grafts; $T I A$, transient ischemic attack; $L V D$, left ventricular dysfunction; $C H F$, congestive heart failure.

placebo, 5.7\% with MC-1 $250 \mathrm{mg}$, and $6.0 \%$ with MC-1 $750 \mathrm{mg}$.

\section{Discussion}

The primary result of this study is that MC-1 did not significantly affect the prespecified composite end point of cardiovascular death, nonfatal MI (peak CK-MB level $\geq 50$ $\mathrm{ng} / \mathrm{mL}$ ), and nonfatal cerebral infarction in this phase 2 study of high-risk CABG patients. However, MC-1 administered at a dose of $250 \mathrm{mg}$ daily in the MEND-CABG trial was associated with a decreased risk for major cardiovascular events with the application of higher thresholds of CK-MB applied to the criteria for MI detection in a post hoc analysis. Reductions of $32.3 \%$ and $37.2 \%$ of the combined end point of cardiovascular death, nonfatal stroke, and nonfatal MI were obtained with MC-1 when CK-MB cutoff values of 70 and $100 \mathrm{ng} / \mathrm{mL}$ were used, respectively, in these exploratory analyses. Furthermore, $250 \mathrm{mg}$ of MC-1 reduced MIs with peak CK-MB $\geq 100 \mathrm{ng} / \mathrm{mL}$ by $47.2 \%$. Considering that levels of elevated CK-MB in the post$\mathrm{CABG}$ setting correlate with the extent of myocardial infarction as assessed with magnetic resonance imaging, ${ }^{22}$ post hoc results of the MEND-CABG trial suggest that
MC-1 may be particularly effective in preventing larger, more significant perioperative infarcts.

There is a linear relationship between postoperative CK-MB elevations and 1-year mortality after CABG. ${ }^{23,24}$ In the GUARDIAN trial, peak CK-MB values after CABG of $<25,25$ to 49,50 to 99 , and $\geq 100 \mathrm{ng} / \mathrm{mL}$ were associated with 6-month mortality risks of $3.4 \%, 5.8 \%, 7.8 \%$, and $20.2 \%$, respectively. ${ }^{25}$ In another study of 3812 patients undergoing $\mathrm{CABG}$, the link between peak $\mathrm{CK}-\mathrm{MB}$ and 3-year mortality was shown only in patients with values above $88 \mathrm{ng} / \mathrm{mL}^{26}$ Because of this relationship between $\mathrm{CK}-\mathrm{MB}$ and mortality, several large clinical trials such as PRIMO-CABG have used a cutoff CK-MB value of 100 $\mathrm{ng} / \mathrm{mL}$ to diagnose perioperative MIs. ${ }^{12,13}$ In the present study, the observed incidence of nonfatal MIs in the placebo group of $23.1 \%$ based on criteria utilized for event adjudication (peak $\mathrm{CK}-\mathrm{MB} \geq 50 \mathrm{ng} / \mathrm{mL}$ ) was much higher than the reported $11 \%$ to $14 \%$ incidence in similar populations. $^{11,13,23}$ This higher than expected rate of MIs, in contrast with rates of cardiovascular deaths and nonfatal cerebral infarctions that were those we had predicted, suggest that our cutoff $\mathrm{CK}-\mathrm{MB}$ value used to diagnose MI may have been too low in the peri-CABG setting. When using the 


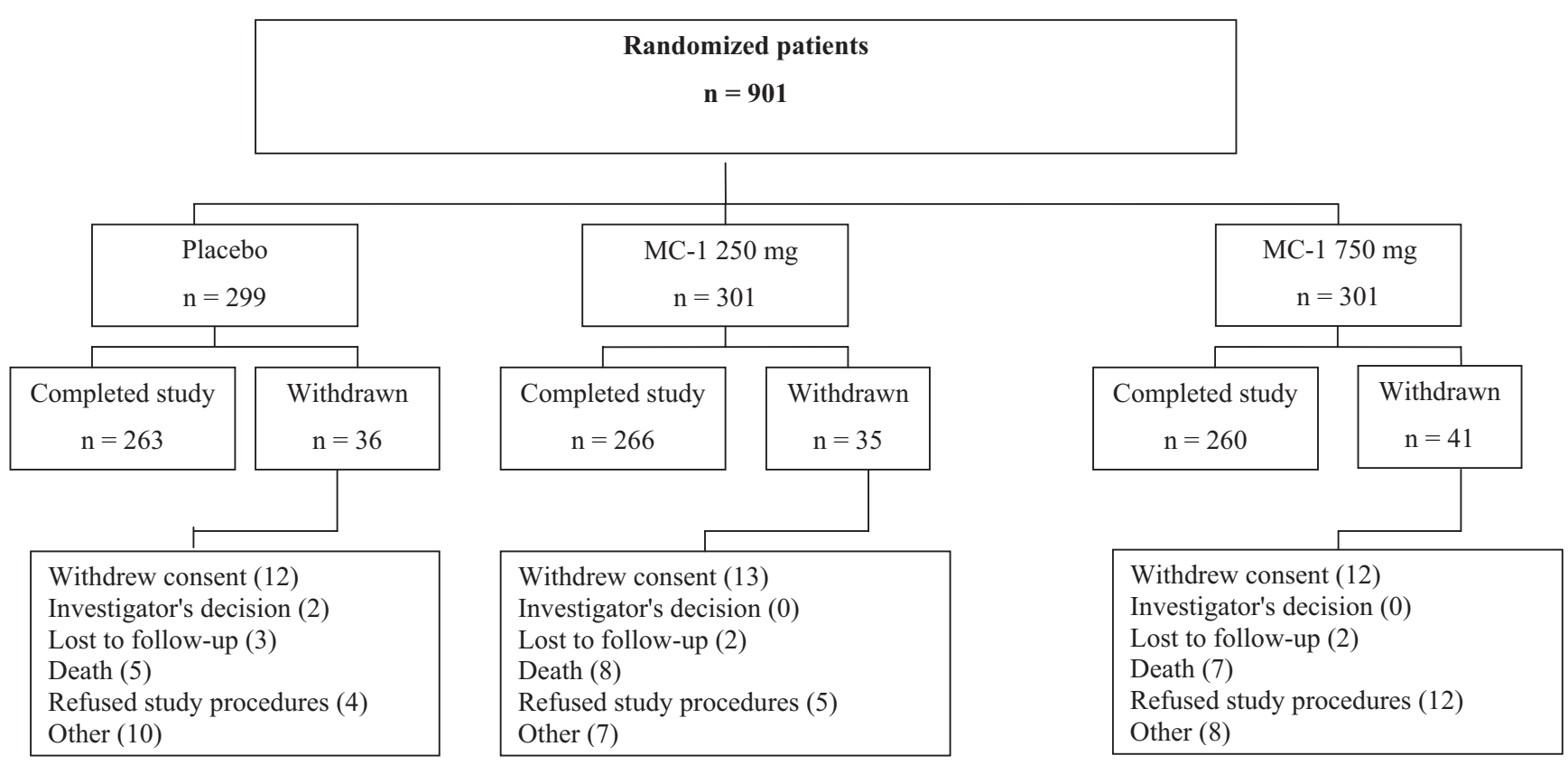

Figure 1. Patient flow in the MEND-CABG study. The 901 randomized patients were all involved in the efficacy analysis using the intent-to-treat approach.

cutoff CK-MB value of $100 \mathrm{ng} / \mathrm{mL}$, the incidence of the composite end point of cardiovascular death, nonfatal cerebral infarction, and nonfatal MI was $16.4 \%$ in the placebo group, in line with the rate $(15 \%)$ we used in our power calculation for this high-risk population.

The reduction in postoperative MIs with $750 \mathrm{mg}$ of MC-1 versus placebo was not larger than that obtained with $250 \mathrm{mg}$ per day. The rate of nonfatal cerebral infarctions also tended to be higher in the 750-mg arm, an observation that was unexpected and perhaps may have been due to the play of chance. However, it is not clear whether the slightly higher incidence of hypotension associated with $750 \mathrm{mg}$ of MC-1 in the first 4 postoperative days could in part be responsible for this finding. In light of these results, the beneficial effects observed with $250 \mathrm{mg}$ of MC-1 suggest that this dosage may be the preferred one in future trials.

TABLE 2. POD 30 efficacy results-composite and component end points

\begin{tabular}{|c|c|c|c|c|}
\hline End point & $\begin{array}{l}\text { Placebo } \\
(\mathrm{n}=299)\end{array}$ & $\begin{array}{l}\text { MC-1 } 250 \mathrm{mg} \\
(\mathrm{n}=301)\end{array}$ & $\begin{array}{l}\text { MC-1 } 750 \mathrm{mg} \\
(\mathrm{n}=301)\end{array}$ & $P$ value \\
\hline $\begin{array}{l}\text { Cardiovascular death, nonfatal MI (peak CK-MB } \\
\geq 50 \mathrm{ng} / \mathrm{mL} \text { ), and nonfatal cerebral infarction }\end{array}$ & $75(25.1 \%)$ & $65(21.6 \%)$ & $77(25.6 \%)$ & $\begin{array}{l}.3124 \text { placebo vs } 250 \mathrm{mg} \\
.8885 \text { placebo vs } 750 \mathrm{mg}\end{array}$ \\
\hline Cardiovascular death & $4(1.3 \%)$ & $4(1.3 \%)$ & $4(1.3 \%)$ & .9999 (overall) \\
\hline Nonfatal MI (peak CK-MB $\geq 50$ ng/mL) & $69(23.1 \%)$ & $59(19.6 \%)$ & $71(23.6 \%)$ & .4393 (overall) \\
\hline Nonfatal cerebral infarction & $5(1.7 \%)$ & $6(2.0 \%)$ & $10(3.3 \%)$ & .3642 (overall) \\
\hline $\begin{array}{l}\text { Cardiovascular death, nonfatal MI (peak CK-MB } \\
\geq 100 \mathrm{ng} / \mathrm{mL} \text { ), and nonfatal cerebral infarction }\end{array}$ & $49(16.4 \%)$ & $31(10.3 \%)$ & $34(11.3 \%)$ & $\begin{array}{l}.0283 \text { placebo vs } 250 \mathrm{mg} \\
.0709 \text { placebo vs } 750 \mathrm{mg}\end{array}$ \\
\hline Nonfatal MI (peak CK-MB $\geq 70$ ng/mL) & $54(18.1 \%)$ & $34(11.3 \%)$ & $38(12.6 \%)$ & $\begin{array}{l}.0407 \text { (overall) } \\
.0192 \text { placebo vs } 250 \mathrm{mg} \\
.0647 \text { placebo vs } 750 \mathrm{mg}\end{array}$ \\
\hline
\end{tabular}

MI, Myocardial infarction; CK-MB, creatinine kinase-myocardial band. 
TABLE 3. POD 90 efficacy results-composite and component end points

\begin{tabular}{|c|c|c|c|c|}
\hline Endpoint & $\begin{array}{l}\text { Placebo } \\
\text { (n = 299) }\end{array}$ & $\begin{array}{l}\text { MC-1 } 250 \mathrm{mg} \\
(\mathrm{n}=301)\end{array}$ & $\begin{array}{c}\text { MC-1 } 750 \mathrm{mg} \\
(\mathrm{n}=301)\end{array}$ & $P$ value \\
\hline $\begin{array}{l}\text { Cardiovascular death, nonfatal MI (peak CK-MB } \\
\geq 50 \mathrm{ng} / \mathrm{mL} \text { ), and nonfatal cerebral infarction }\end{array}$ & $80(26.8 \%)$ & $67(22.3 \%)$ & $78(25.8 \%)$ & .4047 (overall) \\
\hline Cardiovascular death* & $4(1.3 \%)$ & $5(1.7 \%)$ & $4(1.3 \%)$ & .9272 (overall) \\
\hline Nonfatal MI (peak CK-MB $\geq 50 \mathrm{ng} / \mathrm{mL}$ )* & $74(24.7 \%)$ & $60(19.9 \%)$ & $72(23.8 \%)$ & .3327 (overall) \\
\hline Nonfatal cerebral infarction* & $5(1.7 \%)$ & $6(2.0 \%)$ & $11(3.6 \%)$ & .2362 (overall) \\
\hline $\begin{array}{l}\text { Cardiovascular death, nonfatal MI (peak CK-MB } \\
\geq 70 \mathrm{ng} / \mathrm{mL} \text { ), and nonfatal cerebral infarction }\end{array}$ & $61(20.4 \%)$ & $42(14.0 \%)$ & $48(15.9 \%)$ & $\begin{array}{l}.0362 \text { placebo vs } 250 \mathrm{mg} \\
.1516 \text { placebo vs } 750 \mathrm{mg}\end{array}$ \\
\hline $\begin{array}{l}\text { Cardiovascular death, nonfatal MI (peak CK-MB } \\
\quad \geq 100 \mathrm{ng} / \mathrm{mL} \text { ), and nonfatal cerebral infarction }\end{array}$ & $50(16.7 \%)$ & $32(10.6 \%)$ & $35(11.6 \%)$ & $\begin{array}{l}.0299 \text { placebo vs } 250 \mathrm{mg} \\
.0710 \text { placebo vs } 750 \mathrm{mg}\end{array}$ \\
\hline Nonfatal MI (peak CK-MB $\geq 70 \mathrm{ng} / \mathrm{mL}$ ) & $55(18.4 \%)$ & $34(11.3 \%)$ & $38(12.6 \%)$ & $\begin{array}{l}.0289 \text { (overall) } \\
.0144 \text { placebo vs } 250 \mathrm{mg} \\
.0489 \text { placebo vs } 750 \mathrm{mg}\end{array}$ \\
\hline Nonfatal MI (peak CK-MB $\geq 100 \mathrm{ng} / \mathrm{mL}$ ) & $44(14.7 \%)$ & $23(7.6 \%)$ & $23(7.6 \%)$ & $\begin{array}{l}.0037 \text { (overall) } \\
.0059 \text { placebo vs } 250 \mathrm{mg} \\
.0057 \text { placebo vs } 750 \mathrm{mg}\end{array}$ \\
\hline
\end{tabular}

*Comparison of groups by log-rank test. MI, Myocardial infarction; CK-MB, creatinine kinase-myocardial band.

MC-1 was generally well tolerated in this study. The majority of adverse events during the trial were associated with the surgical procedure and not with the study drug. The relatively high incidence of atrial fibrillation, anemia, and pleural effusions was expected in this perioperative setting. The lower incidence of atrial fibrillation observed in the MC-1 groups (5.7\% and 6.0\%) compared with the placebo group (11.9\%) between POD 4 and the end of the trial is intriguing. Whether this result is due to a direct effect of MC-1 on the atria, reduced atrial stretch secondary to the lower incidence of large myocardial infarcts, or represents simply a chance finding cannot be determined in this trial. Considering the incidence and morbidity associated with atrial fibrillation in the postoperative setting, the effect of MC-1 on atrial fibrillation should be carefully evaluated in future studies.

TABLE 4. Safety results*

\begin{tabular}{|c|c|c|c|}
\hline Variable & $\begin{array}{l}\text { Placebo } \\
(n=294)\end{array}$ & $\begin{array}{c}\text { MC-1 } 250 \mathrm{mg} \\
(\mathrm{n}=296)\end{array}$ & $\begin{array}{c}\text { MC-1 } 750 \text { mg } \\
(n=299)\end{array}$ \\
\hline \multicolumn{4}{|l|}{ From randomization to POD 4} \\
\hline Patients experiencing one or more SAEs & $37(12.6 \%)$ & $36(12.2 \%)$ & $42(14.0 \%)$ \\
\hline Percent of SAEs considered by the investigator unlikely or not related to MC-1 & $100 \%$ & $93.9 \%$ & $97.3 \%$ \\
\hline Patients experiencing one or more AEs & $205(69.7 \%)$ & $217(73.3 \%)$ & $216(72.2 \%)$ \\
\hline Percent of AEs considered by the investigator unlikely or not related to MC-1 & $95.0 \%$ & $94.9 \%$ & $94.4 \%$ \\
\hline Atrial fibrillation & $54(18.4 \%)$ & $56(18.9 \%)$ & $63(21.1 \%)$ \\
\hline Anemia & $43(14.6 \%)$ & $52(17.6 \%)$ & $34(11.4 \%)$ \\
\hline Hypotension & $32(10.9 \%)$ & $37(12.5 \%)$ & $39(13.0 \%)$ \\
\hline Nausea & $31(10.5 \%)$ & $23(7.8 \%)$ & $32(10.7 \%)$ \\
\hline \multicolumn{4}{|l|}{ From POD 4 to end of trial } \\
\hline Patients experiencing one or more SAEs & $76(25.9 \%)$ & $80(27.0 \%)$ & $76(25.4 \%)$ \\
\hline Percent of SAEs considered by the investigator unlikely or not related to MC-1 & $94.9 \%$ & $94.8 \%$ & $89.4 \%$ \\
\hline Patients experiencing one or more AEs & $213(72.4 \%)$ & $203(68.6 \%)$ & $213(71.2 \%)$ \\
\hline Percent of AEs considered by the investigator unlikely or not related to MC-1 & $95.6 \%$ & $94.0 \%$ & $93.3 \%$ \\
\hline Pleural effusion & $22(7.5 \%)$ & $27(9.1 \%)$ & $31(10.4 \%)$ \\
\hline Atrial fibrillation & $35(11.9 \%)$ & $17(5.7 \%)$ & $18(6.0 \%)$ \\
\hline Nausea & $18(6.1 \%)$ & $18(6.1 \%)$ & $29(9.7 \%)$ \\
\hline Peripheral edema & $20(6.8 \%)$ & $23(7.8 \%)$ & $22(7.4 \%)$ \\
\hline Vomiting & $10(3.4 \%)$ & $8(2.7 \%)$ & $20(6.7 \%)$ \\
\hline
\end{tabular}

*The safety population was comprised of patients who took $\geq 1$ dose of study medication. $A E$, Adverse event; $S A E$, serious adverse event; $P O D$, postoperative day. 
$\mathrm{P}-5^{\prime}-\mathrm{P}$, the active ingredient of MC-1, is a metabolite of pyridoxine (vitamin $\mathrm{B}_{6}$ ). Although anecdotal evidence suggests a role for vitamin $B_{6}$ in cardiovascular health, recent large-scale clinical trials have failed to demonstrate any benefit. ${ }^{27,28}$ In contrast, MC-1 has shown cardioprotective effects in animal models, and data from phase 2 trials are encouraging. ${ }^{20}$ This discrepancy may be explained by the fact that doses of pyridoxine above $25 \mathrm{mg}$ produce little change in plasma levels of P-5'-P. ${ }^{29}$ Thus, it is not possible to achieve therapeutic plasma levels of P-5'-P (such as those obtained with the doses of MC-1 used in this study) through vitamin $\mathrm{B}_{6}$ supplementation. $\mathrm{MC}-1$ is a purinergic $\mathrm{P} 2$-receptor antagonist that inhibits the binding of adenosine triphosphate (ATP) and thereby decreases calcium flux into cardiomyocytes. $^{30,31}$ Extracellular ATP is released from platelets and nerve endings during various stress conditions, such as ischemia or reperfusion injury, and acts on purinergic P2-receptors on cardiomyocytes to initiate an increase in intracellular calcium. Because calcium overload leads to cell damage and is responsible for cell death during ischemia followed or not by reperfusion, reduction in calcium influx may explain the beneficial effects observed with MC-1 in animal ${ }^{19}$ and clinical ${ }^{20}$ studies. The majority of myocardial infarctions occurred within the first few days after CABG surgery in this study, and the reduction with MC-1 therefore was already observed at POD 4 . The phase 2, MEND-CABG trial extends previous results in a much larger study conducted in a population of patients that was at high risk of cardiovascular events, in the setting of myocardial ischemia and reperfusion.

In conclusion, treatment with MC-1 in high-risk patients undergoing $\mathrm{CABG}$ with cardiopulmonary bypass did not significantly affect the prespecified primary end point but was associated with a significant reduction in perioperative myocardial infarctions in a post hoc analysis using CK-MB thresholds of 70 and $100 \mathrm{ng} / \mathrm{mL}$. A larger, well-powered trial is needed to further evaluate the cardioprotective effects of MC-1.

Dr Tardif holds the Pfizer and Canadian Institutes of Health Research chair in atherosclerosis. We thank the patients who participated, the site investigators and coordinators, the personnel at the Montreal Heart Institute Coordinating Center and Duke Clinical Research Institute, as well as the study committees. Steering committee: J.-C. Tardif (chair), M. Carrier, R. Côté, G. Dupuis, R. Emery, R. Harrington, T. Heinonen, and D. Kandzari. Clinical Endpoint Committee: P. L'Allier (chair), I. Chayer, J. Grégoire, R. Ibrahim, S. Lanthier. Data Safety Monitoring Board: B. Ferguson (chair), A. Allen, C.E. Buller, J.D. Easton, A.M. Lincoff.

\section{References}

1. The Veterans Administration Coronary Artery Bypass Surgery Cooperative Study Group. Eleven-year survival in the Veterans Adminis- tration randomized trial of coronary bypass surgery for stable angina. N Engl J Med. 1984;311:1333-9.

2. Varnauskas E, European Coronary Surgery Study Group. Twelve-year follow-up of survival in the randomized European Coronary Surgery Study. N Engl J Med. 1988;319:332-7.

3. Alderman EL, Bourassa MG, Cohen LS, Davis KB, Kaiser GG, Killip $\mathrm{T}$, et al. Ten-year follow-up of survival and myocardial infarction in the randomized Coronary Artery Surgery Study. Circulation. 1990;82: 1629-46.

4. Nagle PC, Smith AW. Review of recent US cost estimates of revascularization. Am J Manag Care. 2004;10:S320-76.

5. Euro Heart Survey and the National Registries of Cardiovascular Diseases and Patient Management. 2000. European Society of Cardiology. Available from: http://www.escardio.org/NR/rdonlyres/ED6BA61C-A69D4686-975B-CB844D946F88/0/EHS_CVD2004report.pdf.

6. Sezai YY, Orime YY, Tsukamoto SS. Coronary artery surgery results 2000. Ann Thorac Cardiovasc Surg. 2002;8:241-7.

7. Wolman RL, Nussmeier NA, Aggarwal A, Kanchuger MS, Roach GW, Newman MF, et al,for the Multicenter Study of Perioperative Ischemia Research Group (McSPI) and the Ischemia Research Education Foundation (IREF) Investigators. Cerebral injury after cardiac surgery: identification of a group at extraordinary risk. Stroke. 1999; 30:514-22

8. Zamvar VY, Khan NU, Madhavan A, Kulatilake N, Butchart EG. Clinical outcomes in coronary artery bypass graft surgery: comparison of off-pump and on-pump techniques. Heart Surg Forum. 2002;5:10913.

9. Clark RE, Brillman J, Davis DA, Lovell MR, Price TR, Magovern GJ. Microemboli during coronary artery bypass grafting: genesis and effect on outcome. J Thorac Cardiovasc Surg. 1995;109:249-58.

10. Harrison MJG. Neurologic complications of coronary artery bypass grafting: diffuse or focal ischemia? Ann Thorac Surg. 1995;59:1356-8.

11. Jain U. Myocardial infarction during coronary artery bypass surgery. J Cardiothorac Vasc Anesth. 1992;6:612-23.

12. Theroux P, Chaitman BR, Danchin N, Erhardt L, Meinertz T, Schroeder JS, et al. Inhibition of the sodium-hydrogen exchanger with cariporide to prevent myocardial infarction in high-risk ischemic situations. Main results of the GUARDIAN trial. Guard during ischemia against necrosis (GUARDIAN) Investigators. Circulation. 2000;102:3032-8.

13. Verrier ED, Shernan SK, Taylor KM, Van de Werf F, Newman MF, Chen JC, et al, PRIMO-CABG Investigators. Terminal complement blockade with pexelizumab during coronary artery bypass graft surgery requiring cardiopulmonary bypass: a randomized trial. JAMA. 2004;291:2319-27.

14. Coffey CE, Massey EW, Roberts KB, Curtis S, Jones RH, Pryor DB. Natural history of cerebral complication of coronary artery bypass surgery. Neurology. 1983;33:1416-21.

15. Shaw PJ, Bates D, Cartlidge NE, French JM, Heaviside D, Julian DG, et al. Neurologic and neuropsychological morbidity following major surgery: comparison of coronary artery bypass and peripheral vascular surgery. Stroke. 1987;18:700-7.

16. Roach GW, Kanchuger M, Mangano CM, Newman M, Nussmeier N, Wolman R, et al. Adverse cerebral outcomes after coronary bypass surgery. N Engl J Med. 1996;335:1857-63.

17. Mangano DT. Cardiovascular morbidity and CABG surgery-a perspective: epidemiology, costs, and potential therapeutic solutions. J Card Surg. 1995;10(Suppl 4):366-8.

18. Ashley S, Kinsman R, Ridler B, Baker S, on behalf of the Audit and Research Committee of the Vascular Society of Great Britain and Ireland. Fourth National Vascular Database Report 2004.

19. Kandzari DE, Dery JP, Armstrong PW, Douglas DA, Zettler ME, Hidinger GK, et al. MC-1 (pyridoxal 5'-phosphate): novel therapeutic applications to reduce ischaemic injury. Expert Opin Investig Drugs. 2005; 14:1435-42.

20. Kandzari DE, Labinaz M, Cantor WJ, Madan M, Gallup DS, Hasselblad V, et al. Reduction of myocardial ischemic injury following coronary intervention (the MC-1 to Eliminate Necrosis and Damage trial). Am J Cardiol. 2003;92:660-4. 
21. Prineas R, Crow R, Blackburn M. The Minnesota Code Manual of Electrocardiographic Findings. Littleton, MA: John Wright-PSG, Inc; 1982.

22. Steuer J, Bjerner T, Duvernoy O, Jideus L, Johansson L, Ahlstrom H, et al. Visualisation and quantification of peri-operative myocardial infarction after coronary artery bypass surgery with contrast-enhanced magnetic resonance imaging. Eur Heart J. 2004;25:1293-9.

23. Costa MA, Carere RG, Lichtenstein SV, Foley DP, de Valk V, Lindenboom W, et al, on behalf of ARTS Study Group. Incidence, predictors, and significance of abnormal cardiac enzyme rise in patients treated with bypass surgery in the arterial revascularization therapies study (ARTS). Circulation. 2001;104:2689-93.

24. Steuer J, Horte LG, Lindahl B, Stahle E. Impact of perioperative myocardial injury on early and long-term outcome after coronary artery bypass grafting. Eur Heart J. 2002;23:1219-27.

25. Klatte K, Chaitman BR, Theroux P, Gavard JA, Stocke K, Boyce S, et al. Increased mortality after coronary artery bypass graft surgery is associated with increased levels of postoperative creatinine kinasemyocardial band isoenzyme release: results from the GUARDIAN trial. J Am Coll Cardiol. 2001;38:1070-7.
26. Brener SJ, Lytle BW, Schneider JP, Ellis SG, Topol EJ. Association between CK-MB elevation after percutaneous or surgical revascularisation and three-year mortality. J Am Coll Cardiol. 2002;40:1961-7.

27. Bonaa KH, Njolstad I, Ueland PM, Schirmer H, Tverdal A, Steigen T, et al, NORVIT Trial Investigators. Homocysteine lowering and cardiovascular events after acute myocardial infarction. $N$ Engl J Med. 2006;354:1578-88

28. Lonn E, Yusuf S, Arnold MJ, Sheridan P, Pogue J, Micks M, et al, Heart Outcomes Prevention Evaluation (HOPE) 2 Investigators. Homocysteine lowering with folic acid and B vitamins in vascular disease. $N$ Engl J Med. 2006;354:1567-77.

29. Ubbink JB, Serfontein WJ, Becker PJ, de Villiers LS. Effect of different levels of oral pyridoxine supplementation on plasma pyridoxal-5'-phosphate and pyridoxal levels and urinary vitamin B-6 excretion. Am J Clin Nutr. 1987;46:78-85.

30. Wang X, Dakshinamurti K, Musat S, Dhalla NS. Pyrixodal 5-phosphate is an ATP-receptor antagonist in freshly isolated rat cardiomyocytes. J Mol Cell Cardiol. 1999;31:1063-72.

31. Trezise DJ, Bell NJ, Khakh BS, Michel AD, Humphrey PA. P2 purinoceptor antagonist properties of pyridoxal-5-phosphate. Eur J Pharmacol. 1994;259:295-300. 


\section{Appendix E1 Participating Centers}

Canada-Dr Michel Carrier and Micheline Roy (Montreal Heart Institute, Montreal, Quebec); Dr Pierre Ghosn, Nicole Huart, and Suzanne Bisaillon (St-Luc Hospital, Montreal, Quebec); Dr Pierre Pagé, Dr Robert Cossette, and Carole Fortier (Sacré-Coeur Hospital, Montreal, Quebec); Dr Jean-François Morin and Maggie Crecca (Jewish General Hospital, Montreal, Quebec); Dr François Dagenais and Gladys Dussault (Laval Hospital, Quebec City, Quebec); Dr Terry Yau and Katherine Tsang (Toronto General Hospital, Toronto, Ontario); Dr André Lamy and Rosanne Kent (Hamilton Health Sciences Corp, Hamilton, Ontario); Dr Craig Brown, Karen Crane, and Anne Williston (St-John Regional Hospital, St-John, New Brunswick); Dr Camille Hancock Friesen, Dr John Sullivan, Helen Gravel, and Janice MacIsaac (Queen Elizabeth II, Halifax, Nova Scotia); Dr Eric Jamieson and Cindy Bryson (St-Paul's Hospital, Vancouver, British Columbia); Dr Guy Fradet, Rebecca Fox, and Sandy Macleod (Vancouver Hospital, Vancouver, British Columbia); Dr Andrew Maitland and Marg Holland (Foothills Medical Centre, Calgary, Alberta); Dr Khaled Nour, Dr Colette Seifer, and Barbara McEwen (St-Boniface General Hospital, Winnipeg, Manitoba); Dr Benoit de Varennes, Carole Albert, and Connie Vaccaro (Royal Victoria Hospital, Montreal, Quebec).

United States-Dr John Harlan and Juli Burks (Medical Center East, Birmingham, Ala); Dr Bleakley Chandler and Paula Easler (University Hospital, Augusta, Ga); Dr Eric Dippel and Penny Stoakes (Genesis Medical Center, Davenport, Iowa); Dr Clay
Burnett and Sandy Bernhardt (Olathe Medical Center, Olathe, Kan); Dr A. David Slater and Elizabeth Cooke (Jewish Hospital, Louisville, Ky); Dr James C. Todd III and Janine Uhrin (Peninsula Regional Medical Center, Salisbury, Md); Dr Norbert Baumgartner and Kathleen Mostek (Covenant Medical Center, Saginaw, Mich); Dr John Fetter and Liz Zappitello (Saint Mary's Medical Center, Duluth, Minn); Dr Timothy Kroshus and Julia Price (Abbott Northwestern Hospital, Minneapolis, Minn); Dr Nicholas Kouchoukos and Nancy Nickerson (Missouri Baptist Medical Center, St Louis, Miss); Dr Joseph Graham and Rita Stiles (StJohn's Regional Medical Center, Joplin, Miss); Dr David Duncan and Sherry Duncan (Forsyth Medical Center, Winston-Salem, NC); Dr John Alexander and Ann Skye (Duke University Medical Center, Durham, NC); Dr Paul H. Werner and Cheryl Zywicki (Saint Lukes Medical Center, Milwaukee, Wis); Dr Mohammed Quader and Jacque Taylor (University Nebraska Medical Center, Papillion, Neb); Dr Roberto Novoa and Patricia Boyd (Aultman Hospital, Canton, Ohio); Dr Benjamin Sun and Ana Moore (Ohio State University Medical Center, Columbus, Ohio); Dr Anoar Zacharias and Robert Habib (St-Vincent Mercy Medical Center and Saint Luke's Hospital, Toledo, Ohio); Dr Sanjay Mehta and Paula Ulsh (Milton S. Hershey Medical Center, Hershey, Pa); Dr Paul Risher and Eileen Taff (Saint Luke's Hospital, Bethlehem, $\mathrm{Pa}$ ); Dr Robert Hagberg and Jennine Zumbuhl (Sentara Norfolk General Hospital, Norfolk, Va); Dr Frederick Armenti and Sandy Watt (McLaren Regional Medical Center, Flint, Mich). 